\title{
A protocol suggested for management of cantaloupe downy mildew
}

\author{
Abada, K. A. ${ }^{1}$, Kh. E. Eid ${ }^{2}$ \\ ${ }^{1}$ Plant Pathology Department, Faculty of Agriculture, Cairo University, Giza, Egypt \\ ${ }^{2}$ Agric.Bot.Dept., Fac. Agric. at Moshtohor, Benha Univ., Egypt \\ Email address: \\ dr_khairy_abada@yahoo.com (Abada K. A.)
}

\section{To cite this article:}

Abada, K. A., Kh. E. Eid. A Protocol Suggested for Management of Cantaloupe Downy Mildew. American Journal of Life Sciences. Special Issue: Role of Combination Between Bioagents and Solarization on Management of Crown-and Stem-Rot of Egyptian Clover. Vol. 2, No. 6-2, 2014, pp. 1-10. doi: 10.11648/j.ajls.s.2014020602.11

\begin{abstract}
The inhibitory effect of the fungicides Acrobat copper, Previcure- $\mathrm{N}$ and Unilax, the inducer resistance chemicals (IRCs) bion, chitosan, salicylic acid and zinc sulphate and the bioagents Bacillus polymyxa, B. subtilis and Pseudomonas fluorescens on sporangial germination of fungus like Pseudoperonospora cubensis, the causal of cantaloupe downy mildew was tested in vitro. The role of the tested fungicides, IRCs and bioagents on management of cantaloupe downy mildew was evaluated under greenhouse conditions. In addition, the alternation between the sprayed tested fungicide Unilax, IRC chitosan and bioagent P.fluorescens on management of the disease under field conditions was investigated. The inhibitory effect of the tested fungicides, IRCs and bioagents on sporangial germination of $P$. cubensis revealed that they caused significant reduction to the germinated sporangia. The tested fungicides were the most efficient ones followed by the bioagents then IRCs. Disease management showed the same trend of in vitro experiment when they sprayed on artificially inoculated cantaloupe plants with the sporangia of the causal fungus like under greenhouse conditions. Under field conditions, spraying cantaloupe plants with the tested fungicide Unilax still the most efficient trial for management the disease during 2012 and 2013 growing seasons compared with spraying any of IRC (chitosan) and the bioagent (P. fluorescens) alone . However, spraying the tested fungicide in alternation with the tested IRC and the bioagent ranked the second efficiency of disease management. Meanwhile, spraying the tested fungicide in alternation with any of the tested IRC and bioagent was of moderate efficiency.
\end{abstract}

Keywords: Bacterial Bioagents, Cantaloupe, Chemical Control, Downy Mildew, Fungicides and Inducer Resistance Chemicals

\section{Introduction}

Cantaloupe (Cucumis melo L. var. reticulates Ser.) is one of the most famous cucurbit crops in Egypt for local consumption and exportation. It is considered as an untraditional winter crop and became one of the most important exportation crops to the foreign markets. The demand amounts from cantaloupe fruits for local consumption and exportation are annually increased. In addition, Egypt has a relative advantage of increasing the cultivated area and the produced fruit yield, e.g. fertile soil, warm winter, sheep workers, pioneer farmers, enough amounts of water.. ..ect. However, cantaloupe plants are liable to infection by bacterial, fungal and viral diseases in addition to nematode infection and physiological disorders
(Osman, 1966; Abo-El Ghar, 1970; Zitter et al, 1996; Brutan, 1997; Aegerter et al, 2000; Hilal, 2004; Muhanaa, 2006; Colucci, 2008 and Ashour, 2009). Moreover, downy mildew caused by the fungus like Pseudoperonospora cubensis is among the most serious diseases affecting cantaloupe production, with a high severity, especially at the time of fruit maturity (Zitter et al, 1996 and Abdel-Kader, et al, 2012). The optimum symptoms of the disease are angular chlorotic lesions on the foliage growth. These lesions appear angular because they are bound by leaf veins. During humid conditions, inspection of the underside of the leaf reveals gray-brown to purplish-black fungal growth. This downy material is the sporulation of the pathogen. Magnification of 
the sporulation reveals the acutely and dichotomously branched sporangiophores bearing lemon-shaped sporangia. Eventually, leaves will turn necrotic and curl upwards. The disease is sometimes called wildfire because of how rapidly it progresses, as if the crop were burned by fire. The pathogen must overwinter in an area that does not experience a hard frost, and where wild or cultivated cucurbits are present. The spores are dispersed via wind to neighboring plants and fields and often over long distances. Symptoms appear 4 to 12 days after infection. The pathogen thrives under cool and moist conditions, but can do well under a wide range of conditions. Optimum conditions for sporulation are $15-20^{\circ} \mathrm{C}$ with 6 to 12 hours of moisture present, often in the form of morning dew. Even when high daytime temperatures are not favorable for the pathogen $>35^{\circ} \mathrm{C}$, night time temperatures may be very suitable. Oospores of $P$. cubensis are rare and their role in nature is unknown (Zitter,et al., 1996).

It is well known that chemical control of plant diseases greatly causes environmental pollution and increase in the accumulated toxic substances in human food chain. On the other hand, using other trials of disease management, e.g. biological control, plant extracts, antioxidants and agricultural practices, each alone, are not enough to give efficient results (Muhanaa, 2006; Abada et al., 2008; Ashour, 2009). Therefore, this work was aimed to evaluate the efficiency of some systemic fungicides, $I R C$ and bioagents against cantaloupe downy mildew, under greenhouse and filed conditions. Moreover, minimizing fungicides residue in the harvested fruits by spraying them before harvesting the fruits by at least 21 days then spraying IRC and bioagents in alternation until and during harvesting.

\section{Materials and Methods}

\subsection{Effect of Some Fungicides}

IRC and bioagents on sporangial germination

The effect of some fungicides, IRC and bioagents on the sporangial germination of the fungus like P.cubincis was studied in vitro.

a. Preparation of the tested fungicides:

The concentrations of $0.0,25,50,100,150,200,300,400$ and $500 \mathrm{ppm}$. of the fungicides Acrobat copper (dimethmorph + copper oxychloride), Previcure-N (propamocarb hydroxychloride) and Unilax (metalxyl + mancozeb) were prepared depending on the active ingredient of each fungicide.

b. Preparation of IRCs:

The inducer resistance chemicals (IRC) bion, chitosan salicylic acid and zinc sulphate were prepared at $0.0,5,10$, $25,50,75,100$ and $150 \mathrm{mM}$ depending on their molecular weight.

c. Preparation of bioagents:

The bacterial isolates $B$. polymyxa, B. subtilis and $P$. fluorescens (obtained from Soils, Water and Environment Res. Inst., ARC, Giza) were grown on nutrient broth (NB) at
$28 \pm 1^{0} \mathrm{C}$ for $48 \mathrm{~h}$. the bacterial suspension was adjusted to contain $1 \times 10^{:}, 1 \times 10^{2}, 1 \times 10^{3}, 1 \times 10^{4}, 1 \times 10^{5}, 1 \times 10^{6}$ and $1 \times 10^{7}$ $\mathrm{cfu} / \mathrm{ml}$ (Omar et al., 2011).

Cantaloupe leaves naturally infected by the disease were collected from a field located at Imbaba county, Giza governorate and incubated at $20 \pm 1^{\circ} \mathrm{C}$ under humid conditions to encourage sporangial formation. Freshly collected sporangia by sterilized brush from the infected leaves were put in each concentration of the tested fungicides, IRC and bioagents. One ml.of sporangial suspension was placed on two sterilized slides, borne on two glass rods in a sterilized Petri-dish containing a piece of wetted cotton by sterilized distilled water to provide high relative humidity. The same was made for a spore suspension put in distilled sterilized water only as control treatment. Preparations were incubated in darkness at $20 \pm 1{ }^{\circ} \mathrm{C}$ for 48 hour. One drop from lacto- phenol cotton blue stain was added at the time of slide examination to fix and killing the germinated sporangia. Percentage of sporangial germination was counted as empty sporangium (cleared sporangium, which zoospores released out the sporangium) in a total of 100 sporangium. The germinated sporangia were counted and mean of percentages of germination was calculated and recorded for each treatment.

\subsection{Greenhouse Experiment}

The effect of the fungicides Acrobat Copper, Previcure-N and Unilax the IRC bion, chitosane, salicylic acid and zinc sulphate and the bioagents B.polymexa, B. subtilis andP. fluorescens on the severity of cantaloupe downy mildew caused by P.cubensis was carried out using artificial inoculation under greenhouse conditions in order to select the most efficient fungicide and IRC and bioagent to assess their efficiency in management the disease under field conditions, either alone or in different combinations.

Pots (25 $\mathrm{cm}$ in diameter) containing disinfested soil by $5 \%$ formalin were sown with cantaloupe seeds. Five seeds (c.v Galia) were sown in each pot, irrigated and left to grow then thinned into two plants in each pot, 2 weeks after sowing. Five pots were used for each treatment. The grown plants (aged 5 weeks) were sprayed with the tested fungicides at $250 \mathrm{~g}$., $250 \mathrm{ml}$. and $250 \mathrm{gml}$. respectively, IRC at $100 \mathrm{mM}$ and the bioagents at $1 \times 107$ five days before the artificial inoculation with sporangial suspention $\left(1 \times 10^{3}\right)$ of the pathogen. The plants resprayed with tested fungicides, IRC and bioagents at the previous rates 15 days after the inoculation by the tested pathogen. Plants sprayed with sporangial suspension only were left as control treatment. The grown

plants were irrigated when it was necessary and fertilized by the crystalon compounded fertilizer (one g. for each pot), three weeks after sowing and two weeks later.

The severity of the disease was assessed one month after spraying of the fungicides, IRC and bioagents. Also, plant length $(\mathrm{cm})$ as well as foliage fresh weight $(\mathrm{g})$ were assessed and taken into consideration. 


\subsection{Field Experiments}

A piece of land located at Imbaba county, Giza governorate (sandy loamy soil) was prepared for sowing cantaloupe transplants (c.v Galia). Cantaloupe transplants (30 days age) were sown in mulched rows with plastic sheets (42m long) with $40 \mathrm{~cm}$ apart on mid of January of 2012 and 2013. Transplants were grown under low tunnels during low temperature condition at the night until beginning of March and left to grow in the open air until end of the growing season (mid of June) during the two growing seasons. All agricultural practices, i.e. irrigation, weeds and pests control as well as fertilization were applied according to the standard recommendations of Ministry of Agriculture and Land Reclamation.

The fungicide Unilax, the IRC chitosan and the bioagent $P$. fluorescens were evaluated under field conditions, against the natural infection by downy mildew. In this respect, the grown plants were left to the natural infection by the causal fungus like $P$. cubensis then sprayed at the first appearance of downy mildew symptoms by the tested fungicide at 250 $\mathrm{g} / 100 \mathrm{~L}$ water, the tested IRC (at $50 \mathrm{mM}$ )and the bioagent (at $\left.1 \times 10^{7}\right)$ as mentioned in Table (4). Unsprayed cantaloupe plants with the tested fungicide, IRC and the bioagent were left as control treatment. Three rows of $42 \mathrm{~m}$ long were used as a replicate and four replicates were used for each treatment. Disease severity of downy mildew was assessed in each season using the devised scale (0-11) by Horsfall and Barratt (1945) and the averages were recorded. In the same time, fruit yield $\mathrm{Kg} /$ treatment was weighed in each harvesting and the average was calculated and recorded. Also, The percentage of total soluble solids (T.S.S.) of randomized 5 fruits for each treatment were measured using hand fractometer ( Megdam, 2013) and the average was tabulated.

\subsection{Disease Assessment}

Both artificially and naturally infected plants were carefully examined to estimate the severity of the infection by downy mildew depending on the devised scale (0-11) by Horsfall and Barratt (1945) using the following formula:

$$
\text { Disease severity } \%=£(\mathrm{nxv}) \mathrm{X} 10011 \mathrm{~N}
$$

Where:

$\mathrm{n}=$ number of infected leaves in each category.

$\mathrm{v}=$ numericalvalues of each category.

$\mathrm{N}=$ total number of the infected leaves.

\section{Statistical analysis:}

Data were statistically analyzed using the standard procedures for complete randomize block and split designs as mentioned by Snedecor and Cochran (1967). The averages were compared at $5 \%$ level using least significant differences (L.S.D) according to Fisher (1948).

\section{Results}

\subsection{Effect of Three Systemic Fungicides on Sporangial Germination}

Table (1) indicates that the tested systemic fungicides caused significant reduction to the germinated sporangia compared with control treatment. No germination was occurred at $400 \mathrm{ppm}$ by Unilax and at $500 \mathrm{ppm}$ by Acrobat Copper and Previcure-N. In addition, Unilax was the most efficient one followed by Previcure-N then Acrobat Copper, being $27.1,30.8$ and $37.1 \%$ sporangial germination. The inhibitory effect to the sporangial germination was gradually increased by increasing the fungicide concentration. Control treatment recorded $92.6 \%$ sporangial germination.

Table 1. Effect of three systemic fungicides on sporangial germination of $P$. cubinsis, 48 hour after incubation at $20 \pm 1^{\circ} \mathrm{C}$.

\begin{tabular}{|c|c|c|c|c|c|c|c|c|c|}
\hline \multirow{2}{*}{ Fungicides } & \multicolumn{8}{|c|}{ Average percentage of germinated sporangia at ppm. } & \multirow{2}{*}{ Mean } \\
\hline & 25 & 50 & 100 & 150 & 200 & 300 & 400 & 500 & \\
\hline Acrobat Copper & 72.6 & 62.8 & 52.0 & 44.2 & 33.8 & 20.6 & 10.6 & 0.0 & 37.1 \\
\hline Previcure-N & 74.8 & 61.2 & 45.6 & 30.2 & 20.8 & 10.0 & 3.4 & 0.0 & 30.8 \\
\hline Unilax & 70.2 & 58.6 & 41.8 & 25.4 & 14.4 & 6.0 & 0.0 & 0.0 & 27.1 \\
\hline Control & 92.6 & 92.6 & 92.6 & 92.6 & 92.6 & 92.6 & 92.6 & 92.6 & 92.6 \\
\hline Mean & 77.6 & 68.8 & 58.0 & 48.1 & 40.4 & 32.3 & 26.7 & 23.2 & \\
\hline
\end{tabular}

L.S.D. at $5 \%$ for : Fungicides $(\mathrm{F})=2.3$, Concentrations $(\mathrm{C})=2.3$ and $\mathrm{F} \times \mathrm{C}=3.1$.

Table 2. Effect of some inducer resistance chemicals on sporangial germination of $P$. cubensis, 48 hour after incubation at $20 \pm 1{ }^{\circ} \mathrm{C}$.

\begin{tabular}{|c|c|c|c|c|c|c|c|c|c|}
\hline \multirow{2}{*}{ Chemical inducer } & \multicolumn{8}{|c|}{ Average percentage of sporangial germination at (m M.) } & \multirow{2}{*}{ Mean } \\
\hline & 5 & 10 & 25 & 50 & 75 & 100 & 125 & 150 & \\
\hline Bion & 82.6 & 77.8 & 73.0 & 65.2 & 54.8 & 45.6 & 34.6 & 24.6 & 57.3 \\
\hline Chitosan & 78.4 & 72.4 & 65.8 & 55.6 & 46.0 & 33.0 & 18.2 & 0.0 & 46.2 \\
\hline Salicylic acid & 79.2 & 73.4 & 66.0 & 57.0 & 47.0 & 36.8 & 26.2 & 17.0 & 50.3 \\
\hline Zinc sulphate & 82.2 & 78.6 & 72.8 & 65.4 & 56.4 & 46.0 & 35.0 & 25.6 & 57.8 \\
\hline Control & 92.6 & 92.6 & 92.6 & 92.6 & 92.6 & 92.6 & 92.6 & 92.6 & 92.6 \\
\hline Mean & 83.0 & 78.9 & 74.0 & 67.2 & 65.4 & 50.8 & 41.3 & 32.0 & \\
\hline
\end{tabular}

L.S.D. at $5 \%$ for: Inducer resistance chemicals $(\mathrm{I})=2.1$, Concentrations $(\mathrm{C})=2.7$ and $\mathrm{I} x \mathrm{C}=3.5 .3$. 


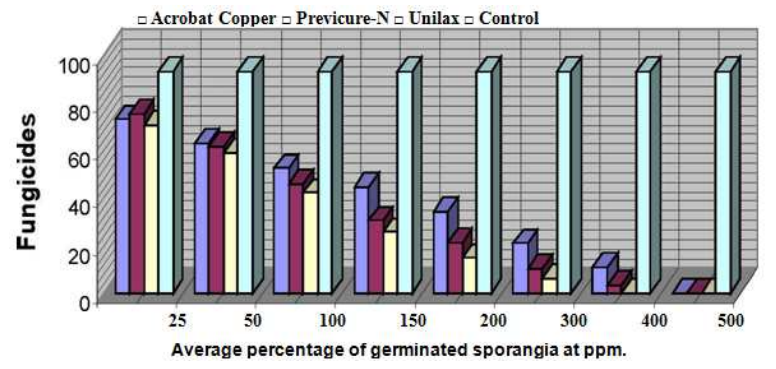

Fig 1. Effect of three systemic fungicides on sporangial germination of $\mathrm{P}$. cubinsis, 48 hour after incubation at $20 \pm 1{ }^{\circ} \mathrm{C}$.

\subsection{Effect of Some Inducer Resistance Chemicals on Sporangial Germination}

Data presented in Table (2) reveal that the tested IRCs caused, also, significant reduction to the germinated sporangia compared with control treatment. Chitosan was the most efficient one, being $46.2 \%$ sporangial germination and caused complete inhibition to the germinated sporangia at $150 \mathrm{mM}$ followed by salicylic acid, being $50.3 \%$ sporangial germination. Both bion and zinc sulphate caused, to some what, similar effect on sporangial germination, being 57.3 and $57.8 \%$ sporangial germination. The inhibitory effect to the sporangial germination was gradually increased by increasing the IRCs concentration. Control treatment recorded $92.6 \%$ sporangial germination.

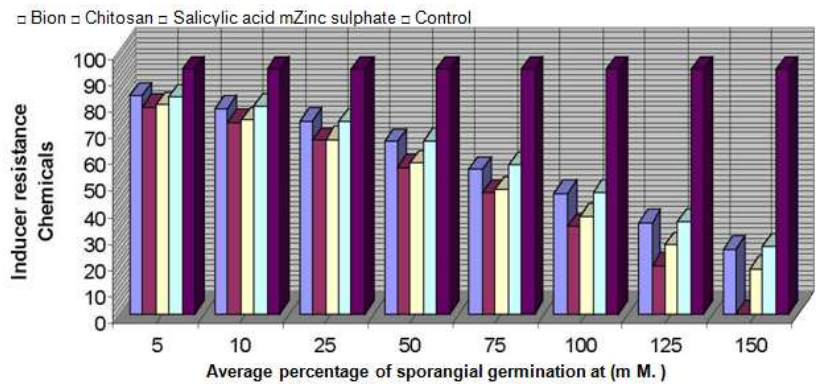

Fig 2. Effect of some inducer resistance chemicals on sporangial germination of $\mathrm{P}$. cubensis, 48 hour after incubation at $20 \pm 1^{\circ} \mathrm{C}$.

\subsection{Effect of Some Bioagents on Sporangial Germination}

Table (3) shows that the three tested bioagents, i.e. B. polymexa, $B$. subtilis and $P$. fluorescens resulted in significant reduction to the germinated sporangia compared with control treatment. However, low effect was found at the concentration of $1 \times 10^{2} \mathrm{cfu} / \mathrm{ml}$, being $91.4,92.6$ and $91.0 \%$ sporangial germination, respectively. The inhibitory effect to the sporangial germination was gradually increased by increasing the concentration of the tested bioagents. In addition, at the concentration of $1 \times 10^{8} \mathrm{cfu} / \mathrm{ml}$ no germination was recorded. Control treatment recorded 93.2 sporangial germination.

Table 3. Effect of some bioagents on sporangial germination of $P$. cubensis, 48 hour after incubation at $20 \pm 1{ }^{\circ} \mathrm{C}$.

\begin{tabular}{|c|c|c|c|c|c|c|c|c|}
\hline \multirow{2}{*}{ Bioagents } & \multicolumn{7}{|c|}{ Average percentage of sporangial germination at $1 \times 10^{x *}$} & \multirow{2}{*}{ Mean } \\
\hline & 2 & 3 & 4 & 5 & 6 & 7 & 8 & \\
\hline B.polymexa & 91.4 & 88.6 & 78.8 & 66.6 & 56.4 & 13.0 & 0.0 & 56.4 \\
\hline B.subtilis & 92.6 & 89.8 & 79.0 & 65.2 & 57.8 & 15.6 & 0.0 & 57.1 \\
\hline P. fluorescens & 91.0 & 87.6 & 76.8 & 62.4 & 53.4 & 10.0 & 0.0 & 54.5 \\
\hline Control & 93.2 & 93.2 & 93.2 & 93.2 & 93.2 & 93.2 & 93.2 & 93.2 \\
\hline Mean & 92.1 & 89.8 & 82.0 & 71.9 & 65.2 & 50.8 & 15.8 & \\
\hline
\end{tabular}

${ }^{*} \mathrm{x}=$ numerical number of concentration. L.S.D. at $5 \%$ for: Inducer resistance chemicals $(\mathrm{I})=2.1$, Concentrations $(\mathrm{C})=2.7$ and $\mathrm{I} x \mathrm{C}=3.5$.

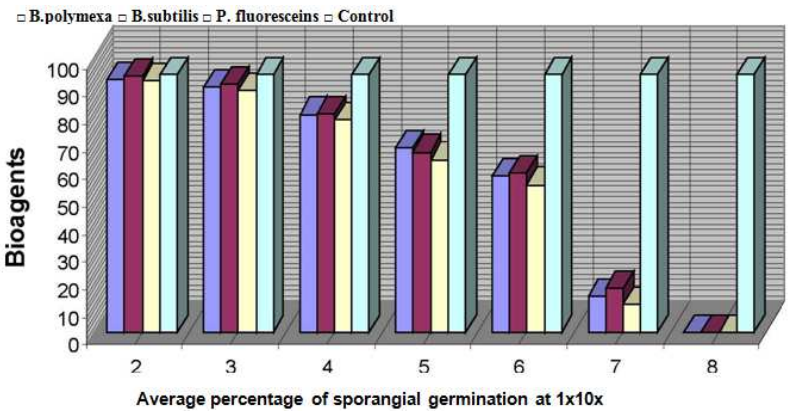

Fig 3. Effect of some bioagents on sporangial germination of $\mathrm{P}$. cubensis, 48 hour after incubation at $20 \pm 1^{\circ} \mathrm{C}$.

\subsection{Greenhouse Experiment}

Results shown in Table (3) show that all the tested fungicides, IRC and bioagents resulted in significant reduction to the severity of downy mildew with significant increase to the plant length and foliage fresh weight of cantaloupe plants compared with control treatment. However, the tested fungicides, i.e Unilax, Previcur-N and Acrobat Copper were more efficient in this regard, being 1.3, 1.8 and $2.2 \%$ disease severity, $102.4,100.8$ and $98.2 \mathrm{~cm}$ plant length, 193.4, 192.1 and 191.6g for foliage fresh weight, respectively, than IRC, i.e. chitosan, bion, salicylic acid and zinc sulphate, being $6.7,8.0,8.0$ and $9.8 \%$ disease severity, 98.2, 96.5, 96.2 and $95.3 \mathrm{~cm}$ for plant length and 191.1, 190.5, 189.8 and $188.0 \mathrm{~g}$ foliage fresh weight, respectively and the bioagents, being 10.8, 10.5 and 9.6\% disease severity, 94.0, 94.1 and $96.3 \mathrm{~cm}$ plant length and $187.3,186.0$ and $190.0 \mathrm{~g}$ foliage fresh weight, respectively. In addition, control treatment recorded $43.7 \%, 44.3 \mathrm{~cm}$ and $131.0 \mathrm{~g}$, respectively. Due to the high efficiency of the fungicide Unilax the IRC chitosan and the bioagent $P$. fluorescens, therefore they were chosen to assess their efficiency in managing the natural infection by the disease in the field in alternation during 2011/2012 and 2012/2013 growing seasons. 
Table 4. Effect of spraying some fungicides, inducer resistance chemicals and bioagents on the severity of cantaloupe downy mildew as well as plant length and foliage fresh weight under greenhouse conditions.

\begin{tabular}{lllll}
\hline Treatment & Fungicides /IRCs / bioagents & \% Disease severity & Average plant length (cm) & Average foliage fresh weight (g)/plant \\
\hline \multirow{3}{*}{ Fungicides } & Acrobat Copper & 2.2 & 98.2 & 191.6 \\
& Previcure-N & 1.8 & 100.8 & 192.1 \\
& Unilax & 1.3 & 102.4 & 193.4 \\
& Bion (B) & 8.0 & 96.5 & 190.5 \\
IRCs & Chitosan (C) & 6.7 & 98.2 & 191.1 \\
& Salicylic acid (SA) & 8.0 & 96.2 & 189.8 \\
& Zinc sulphate & 9.8 & 95.3 & 188.0 \\
& B.poylmyxa & 10.8 & 94.0 & 187.3 \\
Bioagents & B.subtilis & 10.5 & 94.2 & 186.0 \\
& P. fluorescens & 9.6 & 96.3 & 190.0 \\
Control & & 43.7 & 44.3 & 131.0 \\
L.S.D at 5\% & & 2.9 & 2.6 & 2.7 \\
\hline
\end{tabular}

\subsection{Field Experiments}

Table (4) reveals that spraying the fungicide Unilax, the IRC chitosan and the bioagent $P$. fluorescens each alone or in different combinations, on cantaloupe plants resulted in significant reduction to the natural infection by downy mildew compared with control treatment. In addition, the fungicide Unilax was the most efficient in this regard, being $2.2 \%$ disease severity and produced the highest values of fruit yield, being $234.8 \mathrm{Kg} / \mathrm{plot}$ ( 3 rows of $42 \mathrm{~m}$ long) and $15.3 \%$ T.S.S of the harvested fruits, when sprayed alone. On the other hand, spraying chitosan alone as IRC recorded $10.3 \%$ disease severity, $223.4 \mathrm{Kg}$ fruit yield / plot (3 rows of $42 \mathrm{~m}$ long) and $14.7 \%$ T.S.S of the harvested fruits.
Meanwhile, spraying the bioagent $P$. fluorescens alone recorded $12.9 \%$ disease severity and produced $221.1 \mathrm{~kg}$. fruit yield $/$ plot (3 rows of $42 \mathrm{~m}$ long) and $13.9 \%$ T.S.S of the harvested fruits. Furthermore, spraying the fungicide Unilax two sprays followed by spraying the IRC chitosan and the bioagent $P$. fluorescens, each two sprays resulted in intermediate values of disease severity (4.8\%), fruit yield $(230.5 \mathrm{~kg}$.) and T.S.S (14.8\%). Control plants recorded $48.7 \%$ disease severity and gave $137.0 \mathrm{Kg}$ fruit yield/plot (3 rows of $42 \mathrm{~m}$ long) and $12.0 \%$ T.S.S of the harvested fruits.

In all cases no significant effect was detected due to the effect of the growing seasons on the assessed disease severity, fruit yield and their T.S.S.

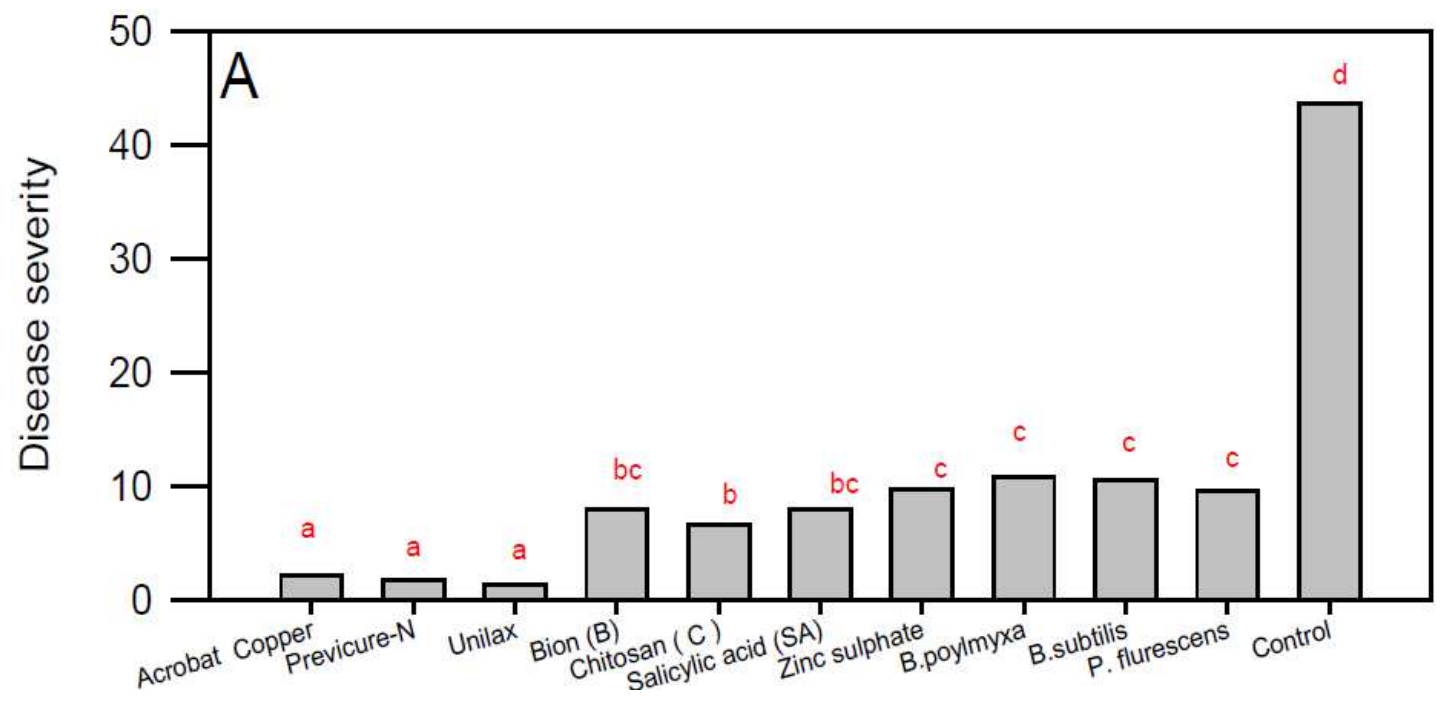



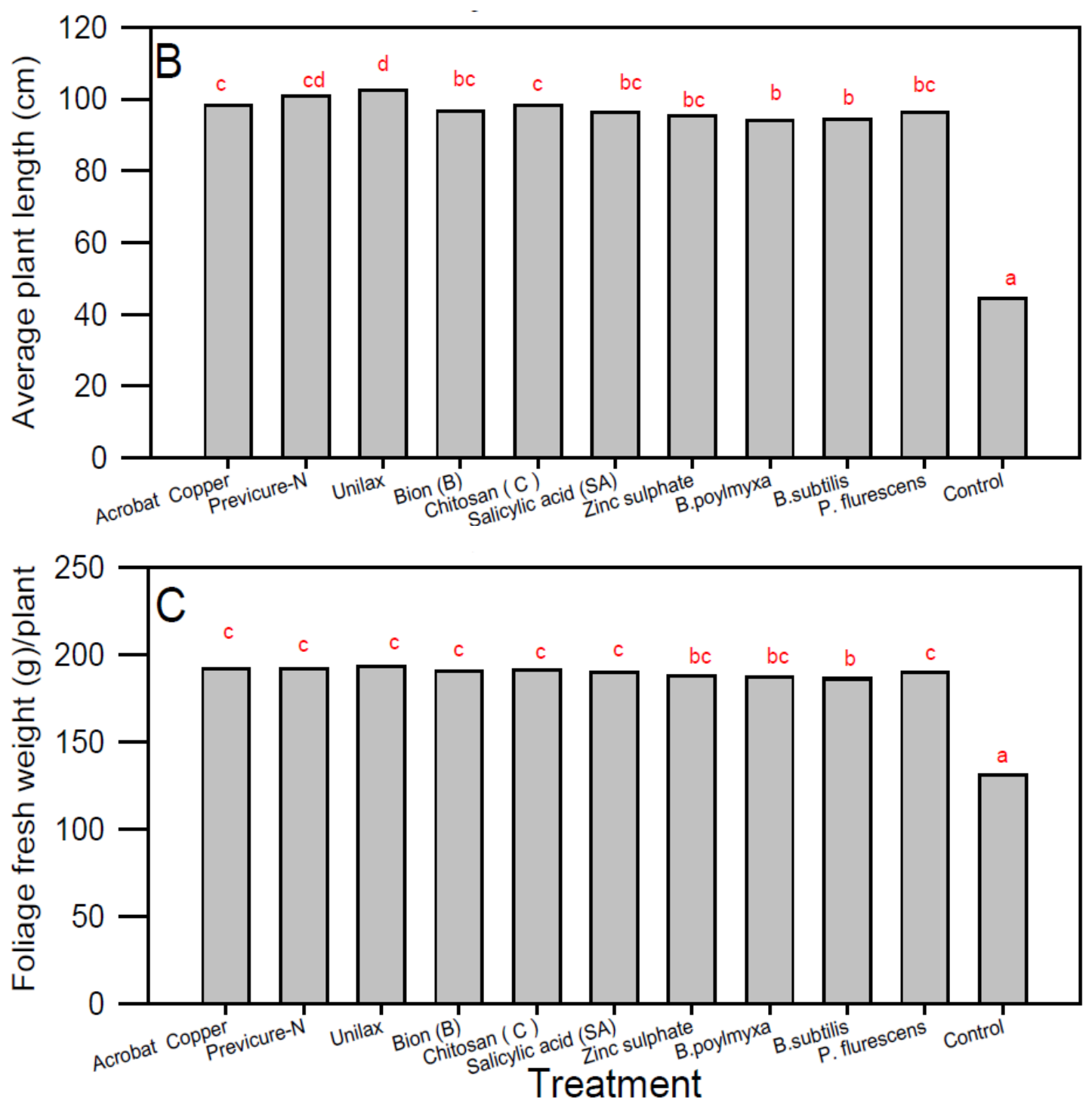

Fig 4. Effect of spraying some fungicides, inducer resistance chemicals and bioagents on the severity of cantaloupe downy mildew as well as plant length and foliage fresh weight under greenhouse conditions.

Table 2. Effect of spraying the systemic fungicide Unilax, the IRC chitosan and the bioagentP. fluorescens in different combinations on the severity of downy mildew, fruit yield and T.S.S. of cantaloupe plants (c.v. Galia), field experiment at Imbaba county during 2012 and 2013 growing seasons.

\begin{tabular}{|c|c|c|c|c|c|c|c|c|c|}
\hline \multirow{2}{*}{ Treatment } & \multicolumn{2}{|c|}{$\begin{array}{l}\text { Disease severity \% } \\
\text { during }\end{array}$} & \multirow{2}{*}{ Mean } & \multicolumn{2}{|c|}{$\begin{array}{l}\text { Average fruit yield } \\
(\mathrm{kg} / \mathrm{plot})^{* * * *} \text { during }\end{array}$} & \multirow{2}{*}{ Mean } & \multicolumn{2}{|c|}{$\begin{array}{l}\% \text {, Average T.S.S. of the } \\
\text { harvested fruits }\end{array}$} & \multirow{2}{*}{ Mean } \\
\hline & 2012 & 2013 & & 2012 & 2013 & & 2012 & 2013 & \\
\hline Unilax(U)* & 2.1 & 2.3 & 2.2 & 235.5 & 234.0 & 234.8 & 15.4 & 15.2 & 15.3 \\
\hline Chitosan (C) & 10.2 & 10.3 & 10.3 & 223.0 & 223.8 & 223.4 & 14.1 & 15.2 & 14.7 \\
\hline P. fluorescens $(P F)$ & 12.9 & 12.2 & 12.6 & 220.7 & 221.5 & 221.1 & 14.0 & 13.8 & 13.9 \\
\hline $\mathrm{U}$ then $\mathrm{C} * *$ & 3.3 & 3.6 & 3.5 & 230.4 & 231.0 & 230.7 & 14.8 & 15.2 & 15.0 \\
\hline $\mathrm{U}$ then PF & 5.0 & 5.4 & 5.2 & 228.0 & 227.7 & 227.8 & 13.8 & 13.9 & 13.9 \\
\hline $\mathrm{C}$ then $\mathrm{PF}$ & 8.3 & 8.1 & 8.2 & 225.5 & 224.0 & 224.8 & 13.5 & 13.7 & 13.6 \\
\hline $\mathrm{U}$ then $\mathrm{C}$ then $\mathrm{PF}^{* * *}$ & 4.6 & 4.9 & 4.8 & 230.0 & 231.0 & 230.5 & 14.9 & 14.6 & 14.8 \\
\hline Control & 48.4 & 49.0 & 48.7 & 138.3 & 135.6 & 137.0 & 12.0 & 11.9 & 12.0 \\
\hline Mean & 11.9 & 12.0 & & 216.4 & 216.1 & & 16.1 & 16.2 & \\
\hline
\end{tabular}

The plants received 6 sprays from each compound when sprayed alone. ** The plants received 3 sprays from each compound when sprayed in alternation. *** The plants received 2 sprays from each compound when sprayed in alternation. **** Each plot 3 rows of $42 \mathrm{~m}$ long. 
L.S.D. at $5 \%$ for:
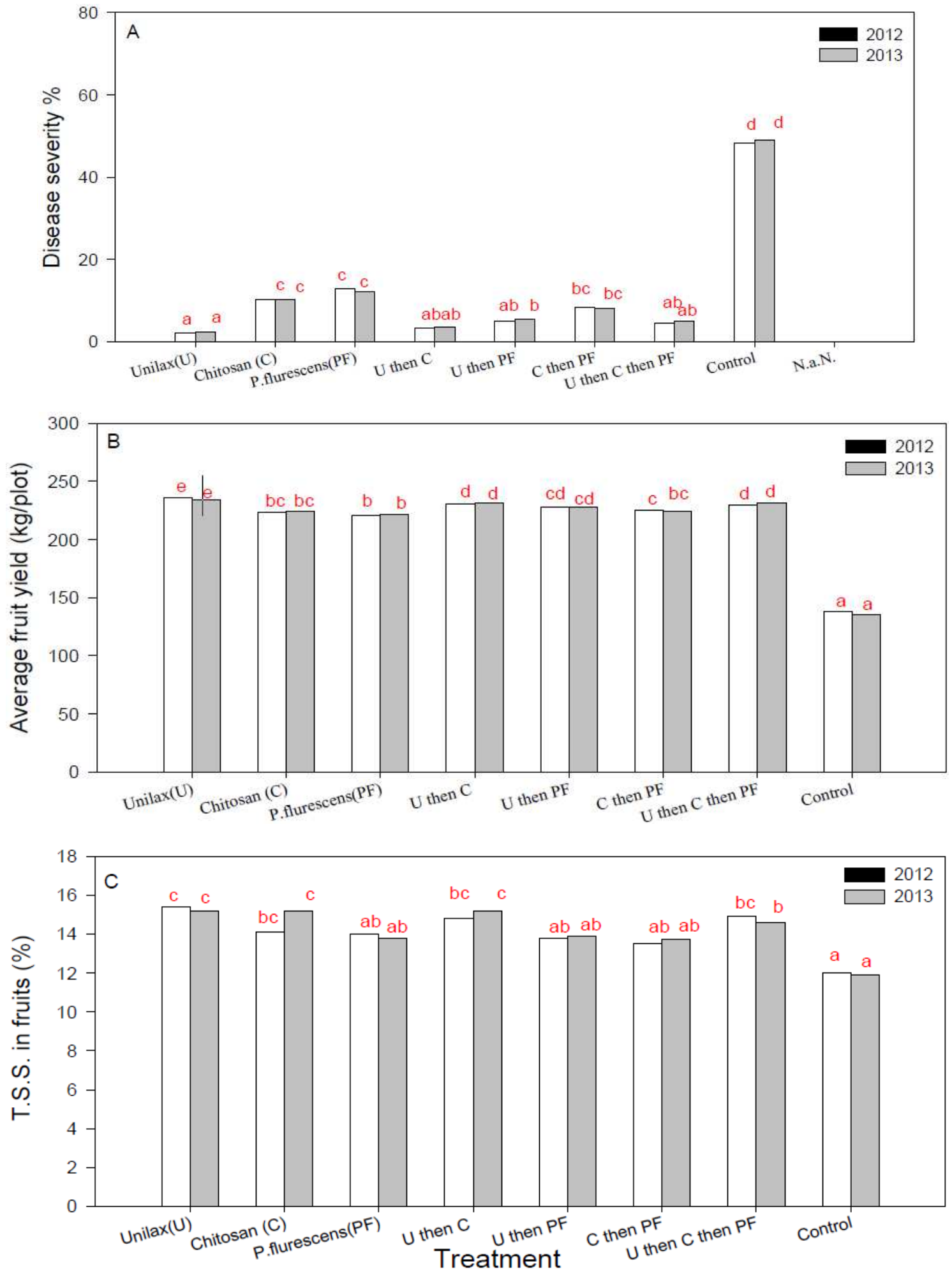

Fig 5. Effect of spraying the systemic fungicide Unilax, the IRC chitosan and the bioagent $\mathrm{P}$. fluorescens in different combinations on the severity of downy mildew, fruit yield and T.S.S. of cantaloupe plants (c.v. Galia), field experiment at Imbaba county during 2012 and 2013 growing seasons.

\section{Discussion}

Nowadays, the world suffers from great pollution from many pollutants including pesticides, especially in the developing countries. Hence, the strategy of management of pests, especially of vegetables and fruits depends on using alternative safe methods for pests management rather than pesticides. Therefore, agricultural scientists recommended 
by using such chemicals at the first period of plant growth prior to the fruit maturity to give a chance to the degradation or lowness of these chemicals to safe compounds before harvesting.

Cantaloupe plants are liable to infection by many fungal diseases; however downy mildew caused by the fungus like Pseudoperonospora cubensis is the most constrain ones. It is an Oomycete pathogen more closely related to water molds such as Phytophthora than to true fungi. The peak of infection reaches its maximum at the time of fruit maturity and harvesting (Colucci, 2008).

There are multiple pathotypes of $P$. cubensis; watermelons, pumpkins, and squash are incompatible with several pathotypes, while cucumbers and cantaloupe are susceptible to them all. There are also several strains within each pathotype, to which various cultivars of each type of cucurbit show varying degrees of susceptibility. P.cubensis can survive and sporulate only on green (living) tissue of the host (Zitter,et al., 1996).

This research aimed to using safe chemicals as IRC, bioagents in alteration with systemic fungicide, which the fungicide sprays at the first period of infection (before fruit maturity) to lowering the infection by the disease for the time of fruit formation until pre-maturity then spraying the IRC and the bioagents before and during harvesting the fruits in order to harvest fruits free or of low fungicides residue and / or of permitted ratio, which are of safe consumption and of high price.

In vitro experiment showed that the tested fungicides, i.e. Acrobat copper, Previcure-N and Unilax, IRC, i.e. bion, chitosan, salicylic acid and zinc sulphate and the bioagents, i.e. Bacillus polymexa, B. subtilis and Pseudomonas fluorescens. However, fungicides were more efficient than IRC and bioagents .

Pot experiment data revealed that the tested fungicides, IRC and bioagents resulted in significant reduction to cantaloupe downy mildew disease with significant increase to plant length and foliage fresh weight compared with control treatment. On the other hand, fungicides were more efficient than IRC and bioagents in this regard.

Field experiment showed that spraying cantaloupe plants with Unilax, chitosan as RIC and P. fluorescens as bioagent caused significant reduction to the disease with significant increment to the harvested fruit yield and their T.S.S. in comparison with control treatment. The combination among the tested fungicide, RIC and bioagent resulted in intermediate effect on reducing the disease, the harvested fruits and their T.S.S. compared with spraying the fungicide alone. In spite of that, the harvested fruits were of low fungicide residue and become of more desirable as safe production, due to the metabolic changes to the sprayed fungicides to be unpoisoned after the long period after the latter fungicide spray.

Chemical control is highly recommended because downy mildew is an aggressive and destructive disease and satisfactory control without the use of fungicides is unlikely. The role of fungicides in reducing the disease is well known
(Mc Grath, 2001) and the role of IRC could be explained by many hypothesis, where induced acquired resistance was induced by restricted infection is not due to a specific component of the pathogen, but rather to gradual appearance and persistence of a level of metabolic perturbation leading to stress on the host.

It is well known that fungicides, especially systemic ones are more efficient in management of many fungal diseases including downy mildew (Mc Grath, 2001; Gisi, 2002 and Ashour, 2009). Also, IRC were reported as alternative and/ or safe trial for management of many diseases, especially those of vegetable crops (Metranx and Boller, 1986; Abo-Taleb, 2001; Hilal, 2004; Muhanna, 2006; Abada et al., 2008; Ashour, 2009 and Abada and Abdel-Malek, 2011).

Doubrava et al. (1988) mentioned that induced acquired resistance is persistent and generally is pathogen nonspecific Larcke (1981) found that unlike elicitors of phytoalexins accumulations, which are elicited at the site of application, may be responsible for localized protection and induces systemic acquired resistance that sensitizes the plant response rapidly after infection. These responses induced phytoalexins accumulation and lignifications and induce enhance activities of chitinase and P-glucanase (Dean and Kuc, 1985 and Metranx and Boller, 1986). Furthermore, Kessmann et al. (1994) reported that the mechanism of systemic acquired resistance is apparently multifaceted, likely resulting in stable broad spectrum disease control and they could be used preventatively to bolster general plant health, resulting in long lasting protection. Iriti and Faoro (2003) reported that bion was used to induce resistance in bean against rust caused by Uromyces appendiculatus. Histochemical and cytochemical investigations showed that BTH causes hydrogen peroxide $\left(\mathrm{H}_{2} \mathrm{O}_{2}\right)$ accumulation in the treated tissues. $\mathrm{H}_{2} \mathrm{O}_{2}$ deposits were localized in situ for the first time in the apoplast of the leaf epidermis. No cell death was detected at BTH concentrations below the phytotoxicity threshold, suggesting that acquired resistance against bean rust is mainly related to the enhanced activity of anionic peroxidases, promoted by $\mathrm{H} 2 \mathrm{O} 2$ accumulation, thereby leading to cell wall strengthening. This hypothesis is also supported by the long induction phase required to establish complete resistance. El-Khallal (2007) reported that both polyphenol oxidase and peroxidase are important in the defense mechanism against pathogens, through their role in the oxidation of phenolic compounds to quinines, causing increasing in antimicrobial activity. Therefore, they may be directly involved in stopping pathogen development; accelerating the cellular death of cells close to the infection site, preventing the advance of infection and/or by generating a toxic environment which will inhibit the growth of the pathogen inside the cells. In addition, several workers suggested two different mechanisms of chitosan molecule and target microorganism interaction: the first is the adsorption of chitosans to cell walls leading to the cell wall covering, membrane disruption and cell leakage; the second is the penetration of chitosans into living cells leading to the inhibition of various enzymes and interference with the 
synthesis of mRNA and proteins (Rabea, 2003, Zheng, and Zhu, 2003 and Atia, et al, 2005).

Biological control has emerged as an alternative and most promising means of the management of plant pathogens. As reported by Trankner (1992) in case of downy mildew disease, Bacillus subtilis grow on the treated surfaces and utilize available nutrient substances and prevent pathogenic spores to establish, germinate and invade healthy tissues. Bacillus sp. also grows very fast and occupies the court of infection and preventing pathogen spores to reach susceptible tissues in competition for spaces. This might be due to that treatments with biopreparation induce systemic resistance as the main mechanism of activity on a plant (Ramamoorthy et al., 2001) or might be due to P. fluorescens produce different types of antibiotics including active 2, 4 diacetyl- phloroglucinole (2,4 DAPB), which control diseases and/or due to that $P$. fluorescens has several methods to control the disease such as production of antifungal compounds including siderophre production, nutrient competition and the induction of systemic resistance. Sarnigute et al. (1995) and Meena et al. (2006) mentioned that the reduction in the infection by that plant pathogens and the increase in the plant length and fresh weight of the treated plants might be due to that $P$. fluorescens produces of indole acetic acid as a growth regulator as well as some antibiotic, i.e. pyrrolnitrin, pyoluterin and 2, 4 diacetyl phloroglucino.

\section{References}

[1] Abada, K.A and A.M. Abdel-Malek,Gehan, 2011. The role of some systemic fungicides and resistance inducing

[2] chemicals on controlling pea downy mildew. Zagazig J. Agric. Res., 38(2): 319-337.

[3] Abada, K.A., R. Mervat Hilal and S.H. Mostafa, 2008. Induced resistance against powdery mildew in

[4] cucumber. J. Biol. Chem. Environ. Sci., 3(3): 45-56.

[5] Abdel-Kader, M.M., Nehal S. El-Mougy, M.D.E. Aly and S.M. Lashin, 2012. Integration of biological and fungicidal aqlternatives for controlling foliar diseases of vegetables under greenhouse conditions. International Journal of Agriculture and Forestry, 2(2): 38-48.

[6] Abo-El Ghar, A.I., 1970. Studies on some viruses affecting cucurbits in Egypt. M.Sc. Thesis, Fac. Agric., Ain Shams Univ., pp: 109.

[7] Abo-Taleb, Mona, M.A., 2001. Biochemical changes associated with application of some resistance inducing

[8] compounds for controlling powdery mildew of cucumber. Egypt. J. Appl. Sci., 16(14): 387-404.

[9] Aegerter, B.J., T.R. Gordon and R.M. Davis, 2000. Occurrence and Pathogenicity of fungi associated with

[10] melon root-rot and vine decline in cantaloupe. Plant Dis., 84: 224-230.
[11] Ashour, A.M.A., 2009. Effect of application of some fungicides and resistance inducing chemicals on

[12] management of cantaloupe powdery mildew. Egypt. J. Phytopathol., 37(1): 1-8.

[13] Atia, M.M.M., H. Buchenauer, A.Z. Aly, M.I. Abou-Ziad, 2005. Antifungal activity of chitosan against Phytophthora infestans and activation of defence mechanisms in tomato to late blight. Biological agriculture \& horticulture, 23: 175-197.

[14] Brutan, B.D., 1997. Occurrence of vine decline disease of melons in Honduras. Plant Dis., 81: 696-705.

[15] Colucci, S., 2008. Host Range, fungicide resistance and management of Pseudoperonospora cubensis, causal

[16] agent of cucurbit downy mildew. M.Sc. Thesis, North Carolina State Univ.

[17] Dean, R.A. and J. Kuc, 1985. Induced systemic protection in plants . TrendsBiotechnol., 3: 125-128.

[18] Doubrava, N., R. Dean and J. Kuc, 1988. Induction of systemic resistance to anthracnose caused by

[19] Colltetrichum lagenarum from spinach and hubar leaves. Physiol. Mol. Plant Pathol., 33: 60-70.

[20] El- Khallal, Samia M., 2007. Induction and modulation of resistance in tomato plants against Fusarium wilt disease by bioagent fungi (arbuscular mycorrhiza) and/or hormonal elicitors (jasmonic acid \& salicylic acid):2-Changes in the antioxidant enzymes, phenolic compounds and pathogen related- proteins. Australian Journal of Basic and Applied Sciences, 1(4): 717-732.

[21] Fisher, R.A., 1948. Statistical Methods $6^{\text {th }}$ ed. Iowa State Univ. Press, Ames, Iowa, USA.

[22] Gisi, U., 2002. Chemical Control of Downy Mildews. In: Advances in Downy Mildew Research. P.T.N.

[23] Spencer-Phillips, U. Gisi and A. Lebeda (eds.). Kluwer Academic Publishers. Dordrecht., pp: 119-159. Hilal, Mervat R., 2004. Induced acquired resistance to cantaloupe powdery mildew by some chemicals under

[24] greenhouse conditions. Egypt. J. Appl. Sci., 19(1): 82-90.

[25] Horsfall, J.G. and R.W. Barratt, 1945. An improved grading system for measuring plant diseases. Phytopathology, 35: 655 .

[26] Iriti, M. and F. Faoro, 2003. Benzothiadiazole (BTH): Induces cell-death independent resistance in Phaseolus vulgaris against Uromyces appendiculatus. J. of Phytopathol, 151(3): 171-180.

[27] Kessmann, H., T. Sataub, C. Hofmann, T. Meatzke and J. Herzog, 1994. Induction of systemic acquired disease resistance in plants by chemicals. Ann. Rev. Phytopathol., 32: 439-459.

[28] Larcke, P., 1981. Alternative chemical agents for controlling plant diseases. Phil. Trans. Res. Soc., 2: 83- 101.

[29] Mc Grath, Margret, T., 2001. Fungicide resistance in cucurbit powdery mildew. PlantDis., 85(3): 236- 250. 
[30] Meena, B., T. Marimuthu and R. Velazhahan, 2006. Role of fluoroscent pseudomonas in plant growth promotion and biological control of late leaf spot of groundnut. Acta Phythopathologica et Entomologica Hungarica, 41(3-4): 203-212.

[31] Megdam, K.A., 2013. Pathological studies on cantaloupe fruit-rot caused by Fusarium spp. M.Sc. Thesis , Fac. Agric., Cairo Univ.

[32] Metranx, J.D. and T. Boller, 1986. Local and systemic induction of chitinase in cucumber plants in response to fungal, bacterial and viral infections. Physiol. Mol. Pathol., 28: 161-169.

[33] Muhanna, Naglaa A.S., 2006. Pathological studies on root-rot and vine decline of cantaloupe in Egypt. Ph.D. Thesis, Fac. Agric., Cairo Univ., pp: 218.

[34] Omar, M.N.A., F. Badr, Salwa, E. Hasan, Maggi and M. Hewait, Heba, 2011. Evaluation of some plant growthpromoting rhizobacteria (PGPR) in inducing resistance of wheat leaf rust under saline conditions. Egypt. J. Phytopathol., 39(1): 111-130.

[35] Osman, Hamida, A., 1966. Studies on the pathogenesis of root knot nematodes Meloidogyne species. M. Sc. Thesis, Fac. Agric. Cairo Univ., p: 41.

[36] Rabea, E.I., M.E.I. Badawy, C.V. Stevens, G. Smagghe, W. Steurbaut, 2003. Chitosan as antimicrobial agent: applications and mode of action. Bio macro molecules, 4: $1457-1465$.
[37] Ramamoorthy, V., R. Viswanathan, T. Raguchander, V. Pkakasam and R. Samivappan, 2001. Induction of systemic resistance by plant growth promoting rhizobacteria in crop plants against pests and diseases in: Crop Protect., 20(1): $1-11$.

[38] Sarnigute, A.J., M.D. Kraus, Lenkels, A.M. Muchlchen and J.E. Loper, 1995. The sigma factor affects antibiotic production and biological control activity of Pseudomonas fluorescens PF-5. Proc. Watl. Acad. Sci., USA , 92: $12255-12259$.

[39] Snedecor, G.W. and W.G. Cochran, 1967. Statistical Methods. $6^{\text {th }}$ Ed. Iowa State Univ. Press, Ames, Iowa, USA.

[40] Trankner, A., 1992. Use of agricultural and municipal organic wastes to develop suppressiveness to plant pathogens. In: E.C. Tjamos, G.C. Papavizas and R.J.Cook, Biological Control of Plant Diseases. Plenum Press, New York, pp: 35-42.

[41] Zheng, L. and J. Zhu, 2003. Study on antimicrobial activity of chitosan with different molecular weights. Carbohydrate Polymer, 54: 527-30.

[42] Zitter, T.A., D.L. Hopkins and C.E. Thomas, 1996. Compendium of Cucurbit Diseases. APS Press, St. Paul, MN. pp: 87. 